\title{
РОЛЬ МЕДСЕСТРИНСЬКОЇ ПЕДАГОГІКИ У ПРАКТИЧНІЙ ДІЯЛЬНОСТІ МЕДИЧНОЇ СЕСТРИ
}

\author{
В. Й. Кульчицький \\ Тернопільський національний медичний університет \\ імені І. Я. Горбачевського МОЗ Украӥни
}

У статті проаналізовано роль медсестринської педагогіки у практичній діяльності медичної сестри. Визначено педагогічні основи навчання пацієнтів у діяльності медичних працівників.

\section{THE ROLE OF NURSING PEDAGOGY IN THE PRACTICE ACTIVITIES OF A NURSE}

\author{
V. Y. Kulchytskyj
}

\section{Horbachevsky Ternopil National Medical University}

The article analyzes the role of nursing pedagogy in the nursing practice activities. The pedagogical bases of patients' teaching are determined in the activities of medical workers.

Вступ. Медсестринська справа - самостійна професія, яка має достатній потенціал, щоб вирішувати проблеми і задовольняти потреби окремих людей та суспільства в цілому, які виникли або можуть виникнути у зв'язку зі змінами здоров'я. Із розвитком суспільства зростає попит на медсестринські послуги, визначаються сфери охорони здоров'я, де потрібною $\epsilon$ не лише увага, а й компетенція та високопрофесійна опіка медичних сестер. Саме наукові дослідження в медсестринстві дозволяють медичним сестрам знайти найкращі способи догляду за пацієнтом, визначити зв'язки між медсестринськими втручаннями та якістю надання медичної допомоги. Зараз повністю змінено погляд на функцію медичної сестри: це і зміцнення здоров'я, профілактика захворювань, забезпечення максимальної незалежності людини відповідно до ії індивідуальних можливостей, надання психосоціальної допомоги усім верствам населення.

Основне завдання медичної сестри-педагога розвиток самостійності пацієнта. Одним із обов'язків медичної сестри $\epsilon$ навчання пацієнта елементам само- та взаємодогляду, дотриманню здорового способу життя, активного пошуку шляхів до якісного життя в умовах хвороби та мотивації до одужання. Саме тому висококваліфікована медична сестра повинна

$\overline{\text { (с) В.Й. Кульчицький, } 2021}$ мати достатньо знань, навичок, а також впевненості, щоб планувати, здійснювати, оцінювати догляд, що відповідає потребам кожного пацієнта.

Основна частина. У процесі формування медсестринська справа постійно зазнавала багатьох змін та удосконалень. Але всі вони мали на меті допомогти хворій людині нормалізувати фізичний і психічний стан, тобто відновити здоров'я пацієнта, створити оптимальні умови для його збереження. Тому однією з функцій медичної сестри, за визначенням Європейського регіонального бюро ВООз, є навчання пацієнтів, як зберегти та відновити здоров'я шляхом:

- оцінки знань і навичок людини, що стосуються збереження і відновлення здоров'я;

- підготовки і надання необхідної інформації на відповідному рівні;

- допомоги медичним сестрам, пацієнтам та іншому персоналу в отриманні нових знань і навичок;

- застосування прийнятих професійних стандартів навчання пацієнтів та членів їх родини [1].

Сучасні дослідники медсестринства у своїх наукових працях звертають особливу увагу на те, що медична сестра повинна допомагати пацієнту самостійно вирішувати проблеми, що виникли в результаті хвороби, навчити його відновлювати здоров'я та вміти зберігати його у майбутньому, тобто чільне місце в 
роботі медичної сестри відводять саме медсестринській педагогіці [1].

Навчання пацієнта - один із методів сестринської діяльності; може бути в формальних умовах (коли медична сестра навчає новим прийомам виконання звичних дій) і неформальних (медична сестра при виконанні своїх обов'язків говорить про проблеми, котрі хвилюють людей, надаючи інформацію, необхідну для дотримання здорового способу життя).

Визначають такі сфери навчання: пізнавальна спрямована на вміння пацієнта аналізувати і синтезувати, а також абстрактно мислити, використовуючи отримані знання і враження; емоційна - характеризує настрій, залежить від емоційних властивостей особистості та вразливості, чуйності, черствості; психомоторна - характеризує зміну настрою, почуттів, рухову активність пацієнта, залежить від психомоторного розвитку особистості, загального самопочуття, нервово-психічних і соматичних захворювань; сочіальнопобутова - відображає громадянську позицію пацієнта, його особистісні та діяльнісні особливості, тобто здібності, інтелект, самооцінку, орієнтацію, працездатність, ставлення до навчання.

Медсестринський догляд і медична допомога мають зробити більше, ніж просто лікувати з метою полегшення страждань. Вони повинні давати можливість пацієнту вчитися, розширювати свої знання для того, щоб він міг сам регулювати власне здоров'я. Мета медсестринської педагогіки полягає в тому, щоб навчити людей приймати правильні рішення щодо власного здоров'я та благополуччя.

Навчання пацієнта має починатися з виявлення та обговорення його проблем. Потім медична сестра переходить до планування разом із пацієнтом відповідних заходів, спрямованих на задоволення цих проблем [2]. Залежно від сприйняття пацієнта виділяють такі види навчання: пасивне сприйняття $i$ освоєння отриманої ззовні інформації - в основі викладання готової інформації, завдань, методів, шляхом повідомлення, роз'яснення, повторення, тренування; активний самостійний пошук і використання інформації- формується під впливом власних інтересів і цілей, це самонавчання спрямоване на задоволення своїх потреб та інтересів; організований ззовні, спрямований пошук і використання інформації - медична сестра формує інтереси пацієнта, на основі яких він здійснює активний відбір і використання необхідної інформації.

Під час навчання пацієнтів медичний працівник застосовує такі методи навчання: пояснювально- ілюстративний; репродуктивний; для візуального сприймання: демонстрація, рольова гра, використання наочності, технічні засоби навчання; для слухового сприймання: обговорення, лекції, аудіозапис; для сприймання на дотик: зворотна демонстрація, практичне вивчення навичок, фізичні моделі.

Для полегшення навчання пацієнта самодогляду медична сестра має використовувати стандартні плани навчання або, при необхідності, власноруч складені індивідуальні плани навчання [1]. Застосування планів навчання документується медичною сестрою в протоколі проведення первинної та поточної оцінки стану пацієнта. Отже, процес навчання пацієнтів включає такі етапи:

- формулювання мотиву;

- оцінку вихідного рівня знань і умінь пацієнта;

- визначення методів, програми, змісту навчання;

- реалізацію плану навчання;

- оцінку процесу навчання, його якості та ефективності.

Необхідно відзначити, що ефективність навчання досягається завдяки ряду умов, а саме: сприятлива, комфортна обстановка; компенсація зниженої здатності до навчання (використовувати минулий досвід, вивчати матеріал постійно); урізноманітнення джерел навчання; вислуховування всього, що говорить чи запитує пацієнт; толерантне ставлення до пацієнтів; оцінка успіхів у навчанні; перерви; заохочення до навчання; постійний контроль навчання.

Під час навчання пацієнтів медичні сестри повинні пам'ятати, що:

- засвоєння знань - це зміна поведінки внаслідок отриманого досвіду;

- шляхи засвоєння знань різними людьми різні;

- люди засвоюють знання з різною швидкістю;

- активізуючи органи чуття слухачів (зір, слух, дотик), а також залучаючи їх до роботи, ви прискорюєте цей процес;

- минулий досвід дорослих слухачів може бути корисним при засвоєнні знань або може ускладнювати їх сприйняття [3].

щоб полегшити процес навчання медична сестра може:

- залучати слухачів до планування занять;

- спільно визначати завдання в процесі навчання;

- застосовувати метод активної участі на заняттях;

- використовувати аудіовізуальні засоби навчання;

- заохочувати до дискусій, обміну досвідом тощо; 
- $з$ повагою та розумінням ставитись до поглядів слухачів та їх культурних традицій [4].

Перед проведенням занять з пацієнтами медичній сестрі варто провести оцінку потреби у навчанні, а саме:

- оцінити спосіб життя пацієнта;

- визначити потребу в самообслуговуванні;

- оцінити соціальне і культурне оточення пацієнта, його вплив на процес навчання;

- оцінити особливості тих, хто навчається: психологічний розвиток, ставлення до навчання, індивідуально-психологічні особливості (увага, осмислення, розуміння, пам'ять);

- оцінити потребу в інформації стосовно: системи охорони здоров'я, рівня медобслуговування, запобігання захворюванням, визначення різних симптомів, інформації про шкідливість тютюну, алкоголю, наркотиків, раціонального харчування, загартування.

Також необхідно провести оцінку початкового рівня знань та умінь пацієнта:

- визначення знань та вмінь, які має людина;

- з'ясування ставлення до інформації;

- врахування факторів: вік, освіта, рівень знань, емоційна зрілість, стан здоров'я, самопочуття, лікарський діагноз;

\section{СПИСОК ЛІТЕРАТУРИ}

1. Медсестринський процес. Основи сестринської справи та клінічного медсестринства / І. Я. Губенко, О. Т. Шевченко, Л. П. Бразалій, В. Г. Апшай. - К. : Здоров'я, 2001. - 208 c.

2. Медсестринський догляд за пацієнтом / І. Я. Губенко, О. Т. Шевченко, Л. П. Бразалій, В. Г. Апшай. - К. : Здоров'я, 2000. -248 c.

3. Губенко І. Я. До питання поєднання медсестринської освіти та практики на основі запровадження мед-
- стан психічних функцій;

- бар'єри навчання: низький рівень грамотності, фізичні перешкоди, соціально-економічні чи культурні фактори, комунікативні бар'єри $[5,6]$.

Таким чином, медична сестра, крім догляду за пацієнтом, виконує роль провідника до здоров'я та здорового способу життя, допомагає набути йому впевненості у власних силах.

Висновки. Необхідно наголосити на тому, що реформа сестринської справи та освіти в Україні, розвиток медсестринської педагогічної науки, впровадження інтенсивних медичних, педагогічних та інформаційних технологій висувають нові вимоги до сестринського персоналу.

Сьогодні формується сучасна концепція сестринської справи, оскільки вона виокремлюється в самостійну сферу медицини. Зростання ефективності медичної допомоги за умови високого рівня освіти середнього медичного персоналу дає змогу проводити диференціювання сестринської діяльності, удосконалювати стандарти долікарської медичної допомоги, визначати і нормувати потреби пацієнта в медичних послугах, здійснювати контроль і облік медичної допомоги.

сестринського процесу / І. Я. Губенко, О. Т. Шевченко, Л. П. Бразалій // Медична освіта. - 2007. - № 4. - С. 29-33.

4. Пасєчко Н. В. Основи сестринської справи (курс лекцій) / Н. В. Пасєчко. - Тернопіль : Укрмедкнига, 1999. 496 c.

5. Шевченко О. Т. Психологія кризових станів: навчальний посібник / О. Т. Шевченко. - К. : Здоров'я, 2005. - 120 с.

6. Пікон К. С. Американський досвід організації ступеневої медсестринської освіти / К. С. Пікон // Молодий вчений. - 2016. - № 12.1 (40). - С. 507-510.

Отримано 15.02.21 